\title{
Effect of the Improved Fermentation on Physicochemical Properties and Sensorial Acceptability of Sour Cassava Starch
}

\author{
Maria Janete Angeloni Marcon, Gisele Cristina Netto Vieira, Karina Nunes de Simas, \\ Karina Santos, Manoela Alano Vieira, Renata Dias de Mello Castanho Amboni and Edna \\ Regina Amante* \\ Departamento de Ciência e Tecnologia dos Alimentos; Centro de Ciências Agrárias; Universidade Federal de \\ Santa Catarina; Rodovia Admar Gonzaga, 1346; Itacorubi; eamante@cca.ufsc.br; 88034-001; Florianópolis - \\ SC - Brasil
}

\begin{abstract}
The aim of this work was to study the effect of improved fermentation on sour cassava starch, aiming to reduce its fermentation time and to enhance its expansion capacity as well as its viscoamylographic properties and its sensorial acceptability. Results showed that the improved process of cassava starch production did not harm starch expansion, physicochemical properties or sensorial acceptability; it also produced starches with different viscoamylographic properties, which compared favourably to those of the sour cassava starch produced through current industrial methods.
\end{abstract}

Key words: Sour cassava starch, expansion, viscosity, sensorial acceptability

\section{INTRODUCTION}

Sour cassava starch (Polvilho azedo) is a typical Brazilian product, preferred in culinary as an indispensable raw material for biscuit and cheesebread production, characterised as soft bulky ovencooked products due to the expansion property of sour cassava starch (Ascheri and Vilela, 1995; Silveira et al., 2000; Balagopalan, 2002). Cassava starch is extracted from cassava root (Manihot esculenta, Crantz) and fermented for 30 to 60 days. This is followed by sun drying, an essential procedure in sour cassava starch finishing. Sour cassava starch, added to biscuit and bread formulations, without flour or ferment, produces dough with a soft alveolar structure, with a large capacity for expansion and crunchiness (Cereda, 1987; Plata-Oviedo and Camargo, 1995; Balagopalan, 2002).

Several works have shown that the fermentative process alters the starch granule, giving sour cassava starch its peculiar characteristics, such as its unique odour and taste, in addition to rheological modifications (Carvalho et al., 1996; Pereira et al., 1999; Maeda and Cereda, 2001; Guyot and Morlon-Guyot, 2001). Studies have shown that sour cassava starch has physical, chemical and functional properties, which are distinct from the original cassava starch. A good example of this is the decrease in volume when sour cassava starch is substituted with cassava starch in biscuit production (Mendes da Silva et

\footnotetext{
${ }^{*}$ Author for correspondence
} 
al., 1998; Maeda and Cereda, 2001). It is generally accepted among researchers that the fermentation and the sun drying processes not only alter starch rheology but also increase expansion capacity and viscosity. Such processes also reduce its initial pasting temperature, resistance to shaking, and gelling tendency on cooling, when compared to the original cassava starch (Maeda and Cereda, 2001).

Considering that biscuits are valued and marketed according to their volume, expansion property is one of the most significant product parameters in quality evaluation of sour cassava starch (Rivera, 1997; Maeda and Cereda, 2001). Maeda and Cereda (2001) suggested a classification to evaluate sour cassava starch quality: type A - sour cassava starch with an expansion rate higher than $16.0 \mathrm{~mL} \cdot \mathrm{g}^{-1}$, type B - between 12.0 and $15.0 \mathrm{~mL} . \mathrm{g}^{-}$ ${ }^{1}$ and type $\mathrm{C}-$ rate lower than $12.0 \mathrm{~mL} \cdot \mathrm{g}^{-1}$. Pereira et al. (1999) suggested expansion rate as being a relation between cookie diameter before and after baking.

Marcon (2004) reported that the addition of glucose syrup to the cassava starch fermentation process could significantly reduce fermentation time, which was an important alternative in accelerating the cassava starch fermentative process in cold regions. The objective of this study was to verify if fermentation improved through glucose addition, as suggested by Marcon (2004), influenced on the characteristic properties of sour cassava starch.

\section{MATERIALS AND METHODS}

Sour cassava starch (polvilho azedo) was produced from samples of cassava starch (Manihot esculenta Crantz) obtained from three different regions in Santa Catarina State (Brazil): Santa Rosa, Rio do Sul and Tubarão. It was produced in laboratory through traditional methodology (no glucose added), and through improved method by adding glucose at concentrations of $0.10 ; 0.25$ and $0.50 \%$ of the volume of the recipients, according to the method described by Marcon (2004). Samples of both cassava starch and industrial sour cassava starch from each of these regions (Table 1) were also used. The analyses were all carried out in triplicate.

Table 1 - Sample Identification.

\begin{tabular}{ll}
\hline Samples & \multicolumn{1}{c}{ Discrimination } \\
\hline RS S & Cassava starch, Rio do Sul \\
RS SS & Sour cassava starch, Rio do Sul (Industrial) \\
RS T & Traditional sour cassava starch, Rio do Sul cassava starch* \\
RS 0.10 & Sour cassava starch fermented with 0.10 \% of glucose, Rio do Sul cassava starch* \\
RS 0.25 & Sour cassava starch fermented with $0.25 \%$ of glucose, Rio do Sul cassava starch* \\
RS 0.50 & Sour cassava starch fermented with 0.50 \% of glucose, Rio do Sul cassava starch* \\
TB S & Cassava starch, Tubarão \\
TB SS & Sour cassava starch, Tubarão (Industrial) \\
TB T & Traditional sour cassava starch, Tubarão cassava starch* \\
TB 0.10 & Sour cassava starch fermented with 0.10 \% of glucose, Tubarão cassava starch* \\
TB 0.25 & Sour cassava starch fermented with 0.25\% of glucose, Tubarão cassava starch* \\
TB 0.50 & Sour cassava starch fermented with 0.50 \% of glucose, Tubarão cassava starch* \\
SR S & Cassava starch, Santa Rosa do Sul \\
SR SS & Sour cassava starch, Santa Rosa do Sul (Industrial) \\
SR T & Traditional sour cassava starch, Santa Rosa do Sul do Sul cassava starch* \\
SR 0.10 & Sour cassava starch fermented with 0.10 \% of glucose, Santa Rosa do Sul cassava \\
SR 0.25 & Starch* \\
SR 0.50 & Sour cassava starch fermented with $0.25 \%$ of glucose, Santa Rosa do Sul cassava \\
*Samples produced in the laboratory from respective regional cassava starch.
\end{tabular}




\section{Physicochemical analysis}

All the samples were analysed in triplicate $(n=3)$, for moisture (AOAC 921.10, 1999), lipid (AOAC 920.39, 1999), crude protein (AOAC 920.87, 1999) and total ash content (AOAC 923.03, 1999).

\section{Determination of Acid factor and $\mathrm{pH}$}

Samples of $25 \mathrm{~g}$ were weighed, with addition of distilled water up to a volume of $50 \mathrm{~mL}$. Sample homogenisation was performed with a magnetic stirrer and $\mathrm{pH}$ evaluation was performed on a pHmeter Quimis model Q 400 A. The suspension was titrated with a standard $0.1 \mathrm{~N} \mathrm{HCl}$ solution to $\mathrm{pH}$ 3.0. The acid factor corresponds to the volume of acid consumed (Brasil, 1978).

\section{Rheological properties}

Viscoamylographic properties were determined in a Brabender Viscoamylograph. Suspensions of 6 $\%$ dry basis weight were prepared, heated at $92{ }^{\circ} \mathrm{C}$, for 10 minutes and cooled to $55^{\circ} \mathrm{C}$ (Mazurs et al., 1957). Gelling point, maximal viscosity, viscosity at 80 and $90{ }^{\circ} \mathrm{C}$, viscosity at $90^{\circ} \mathrm{C}$ for 10 more minutes, and viscosity at $55^{\circ} \mathrm{C}$ were observed.

\section{Expansion capacity}

The determination of expansion capacity followed the procedures proposed by the CERAT - Centro de Raizes Tropicais (Maeda and Cereda, 2001). The biscuits were formulated with $50 \mathrm{~g}$ of sample mixed with $40 \mathrm{~mL}$ of boiling water. The dough was then divided into five parts, shaped into circular biscuits of approximately $10 \mathrm{~g}$ each and baked at $200^{\circ} \mathrm{C}$ for 25 minutes in electrical oven. The biscuits were measured with a pachymeter, before and after baking. Expansion capacity was calculated by using the relation between the initial medial diameter of the biscuits before baking and final medial diameter after baking. All the measurements were performed in triplicate.

\section{Specific volume}

Specific volume of the biscuits was determined through the rape seed displacement method (Cereda, 1983a).

\section{Sensorial analysis}

Glucose syrup at a concentration of $0.50 \%$ was shown by Marcon (2004) to be the most indicated, among the glucose syrup concentrations studied, to improve productivity in the cassava starch fermentation process, thus, justifying the use of sour cassava starch from this process in the evaluation of sensorial acceptability. Biscuits formulated according to Cereda (1983) were evaluated for overall acceptability by 50 volunteers. A nine-point hedonic scale ranged from "like extremely" to "dislike extremely", corresponding to the highest and lowest scores of "9" and "1", respectively, was used. The product acceptability rate (AI) was calculated, where AI $(\%)=\mathrm{A} X 100 / \mathrm{B}$, and $\mathrm{A}$ was the minimal score and $\mathrm{B}$ was the maximal score attributed to the product. An excellent AI should be considered equal to or higher than $70 \%$ (Meilgaard et al., 1999).

Biscuits were prepared by using a standard formulation containing sour cassava starch (75 g), hydrogenated vegetal fat (15 g), salt $-\mathrm{NaCl}(3 \mathrm{~g})$, boiling water (approximately $50 \mathrm{~mL}$, according to the consistency characteristics of each sour cassava starch) (Cereda, 1983). The biscuits were baked in electric oven at $200{ }^{\circ} \mathrm{C}$ for 20 minutes.

\section{Statistical analysis}

All analytical determinations were carried out in triplicate. The data were subjected to analysis of variance. If a significant $F$-test was noted, means were separated by using Tukey multiple range test. Significance was accepted at $p \leq 0.05$.

\section{RESULTS AND DISCUSSION}

The effect of the improved method of sour cassava starch fermentation on product quality was evaluated for moisture, proteins, lipids, ash content, acid factor and $\mathrm{pH}$ (Table 2). The sun drying conditions of the laboratory production of the sour cassava starch samples resulted in significantly higher moisture content, compared to industrial sour cassava starch. Cereda $(1983,1985)$ and Ascheri and Vilela (1995) found moisture values varying from 7.70 to $17.70 \%$. This difference could be attributed to empirical observation for moisture in the sour cassava starch industry. In this work, $6.92 \%$ of the samples analysed showed values in agreement with the maximal limits established for sour cassava starch, which was $14 \%$ moisture (Brasil, 1978).

All the samples showed ash values inferior to the maximal limit permitted by Brazilian laws, which was $0.50 \%$ (Brasil, 1978); for type 1 samples, the 
permitted ash content was $0.12 \%$ and for type 2 was $0.50 \%$. Cárdenas and Buckle (1980), Cereda (1985), Cereda et al., (1995), Aschieri and Vilela (1995) and Plata-Oviedo and Camargo (1995) found ash values that varied from 0.05 to $0.54 \%$, attributed to the sun drying process. The ash content of the treatments on the Santa Rosa do Sul and Rio do Sul starches did not show statistical differences $(p>0.05)$; however, the treatments on the Tubarão products showed statistical difference between one another $(\mathrm{p}<0.05)$.

The products from Rio do Sul and Santa Rosa do Sul did not show significant differences in protein and lipid content, compared to their respective cassava starch and industrial sour cassava starch.
The Tubarão samples showed a significant increase $(p<0.05)$ in protein content after the fermentation process, compared to those from other locations. Nakamura et al. (1976); Cereda and Lima (1981); Plata-Oviedo and Camargo (1995) and Aschieri and Vilela (1995) reported sour cassava starch protein values of 0.60 to 1.83 $\%$, while Cárdenas and Buckle (1980) and Pereira et al. (1999) found values around $0.10 \%$. The values of lipids found in this study were similar to those reported by Pereira et al. (1999) and higher than those reported by Cereda (1983a), Aschieri and Vilela (1995).

Table 2 - Physicochemical of cassava starch (S), industrial sour cassava starch (SS), traditional sour cassava starch (T) and sour cassava starch fermented with $0.10,0.25,0.50 \%$ of glucose, obtained from three different regions of Santa Catarina state (Brazil).

\begin{tabular}{|c|c|c|c|c|c|c|c|}
\hline Region & Treatments & Moisture & Ash* & Protein* & Lipids* & $\begin{array}{c}\text { Acid } \\
\text { Factor }\end{array}$ & pH \\
\hline \multirow{8}{*}{ Rio do Sul } & & $\left(\mathrm{g} .100 \mathrm{~g}^{-1}\right)$ & $\left(\mathrm{g} .100 \mathrm{~g}^{-1}\right)$ & $\left(\mathrm{g} .100 \mathrm{~g}^{-1}\right)$ & $\left(\mathrm{g} .100 \mathrm{~g}^{-1}\right)$ & $(\mathrm{mL} \mathrm{HCl})$ & \\
\hline & $S$ & $14.07^{\mathrm{b}}$ & $0.13^{\mathrm{a}}$ & $0.09^{\mathrm{a}}$ & $0.20^{\mathrm{a}}$ & $3.75^{\mathrm{b}}$ & $5.98^{\mathrm{a}}$ \\
\hline & SS & $14.75^{\mathrm{b}}$ & $0.15^{\mathrm{a}}$ & $0.12^{\mathrm{a}}$ & $0.21^{\mathrm{a}}$ & $3.57^{\mathrm{b}}$ & $3.77^{\mathrm{c}}$ \\
\hline & $\mathrm{T}$ & $18.41^{\mathrm{a}}$ & $0.15^{\mathrm{a}}$ & $0.11^{\mathrm{a}}$ & $0.17^{\mathrm{a}}$ & $1.44^{\mathrm{a}}$ & $4.05^{\mathrm{b}}$ \\
\hline & $0.10 \%$ & $19.05^{\mathrm{a}}$ & $0.12^{\mathrm{a}}$ & $0.11^{\mathrm{a}}$ & $0.16^{\mathrm{a}}$ & $1.63^{\mathrm{a}}$ & $4.13^{b}$ \\
\hline & $0.25 \%$ & $18.71^{\mathrm{a}}$ & $0.11^{\mathrm{a}}$ & $0.11^{\mathrm{a}}$ & $0.19^{\mathrm{a}}$ & $1.66^{\mathrm{a}}$ & $4.05^{b}$ \\
\hline & $0.50 \%$ & $19.41^{\mathrm{a}}$ & $0.14^{\mathrm{a}}$ & $0.12^{\mathrm{a}}$ & $0.22^{\mathrm{a}}$ & $1.71^{\mathrm{a}}$ & $4.03^{\mathrm{bc}}$ \\
\hline & CV & 7.33 & 2.38 & 14.37 & 8.73 & 27.2 & 8.95 \\
\hline \multirow{5}{*}{ Tubarão } & S & $13.03^{\mathrm{c}}$ & $0.11^{\mathrm{b}}$ & $0.08^{\mathrm{c}}$ & $0.14^{\mathrm{c}}$ & $1.78^{\mathrm{b}}$ & $4.82^{\mathrm{a}}$ \\
\hline & SS & $13.68^{\mathrm{c}}$ & $0.11^{\mathrm{b}}$ & $0.14^{\mathrm{ab}}$ & $0.22^{\mathrm{a}}$ & $3.25^{\mathrm{a}}$ & $3.87^{\mathrm{b}}$ \\
\hline & $\mathrm{T}$ & $18.28^{\mathrm{a}}$ & $0.16^{\mathrm{ab}}$ & $0.15^{\mathrm{b}}$ & $0.20^{\mathrm{ab}}$ & $2.84^{\mathrm{b}}$ & $4.58^{\mathrm{a}}$ \\
\hline & $0.10 \%$ & $16.88^{\mathrm{b}}$ & $0.17^{\mathrm{a}}$ & $0.12^{\mathrm{a}}$ & $0.18^{\mathrm{b}}$ & $1.47^{\mathrm{b}}$ & $3.99^{\mathrm{b}}$ \\
\hline & $0.25 \%$ & $17.60^{\mathrm{ab}}$ & $0.13^{\mathrm{ab}}$ & $0.14^{\mathrm{ab}}$ & $0.18^{\mathrm{b}}$ & $1.72^{\mathrm{b}}$ & $4.27^{\mathrm{ab}}$ \\
\hline \multirow{9}{*}{ Santa Rosa } & $0.50 \%$ & $17.56^{\mathrm{ab}}$ & $0.14^{\mathrm{ab}}$ & $0.14^{\mathrm{ab}}$ & $0.19^{\mathrm{b}}$ & $1.52^{\mathrm{b}}$ & $3.93^{\mathrm{b}}$ \\
\hline & CV & 6.31 & 3.57 & 20.03 & 8.70 & 20.96 & 3.84 \\
\hline & S & $12.99^{\mathrm{c}}$ & $0.16^{\mathrm{a}}$ & $0.10^{\mathrm{a}}$ & $0.17^{\mathrm{a}}$ & $2.12^{\mathrm{b}}$ & $5.07^{\mathrm{a}}$ \\
\hline & SS & $14.15^{b}$ & $0.14^{\mathrm{a}}$ & $0.10^{\mathrm{a}}$ & $0.18^{\mathrm{a}}$ & $4.02^{\mathrm{a}}$ & $4.27^{b}$ \\
\hline & $\mathrm{T}$ & $16.02^{\mathrm{a}}$ & $0.14^{\mathrm{a}}$ & $0.11^{\mathrm{a}}$ & $0.19^{\mathrm{a}}$ & $2.16^{\mathrm{b}}$ & $4.12^{c}$ \\
\hline & $0.10 \%$ & $15.56^{\mathrm{a}}$ & $0.13^{\mathrm{a}}$ & $0.09^{\mathrm{a}}$ & $0.21^{\mathrm{a}}$ & $2.06^{\mathrm{b}}$ & $4.14^{\mathrm{c}}$ \\
\hline & $0.25 \%$ & $16.16^{\mathrm{a}}$ & $0.15^{\mathrm{a}}$ & $0.12^{\mathrm{a}}$ & $0.19^{\mathrm{a}}$ & $1.71^{\mathrm{c}}$ & $4.09^{c}$ \\
\hline & $0.50 \%$ & $15.86^{\mathrm{a}}$ & $0.15^{\mathrm{a}}$ & $0.14^{\mathrm{a}}$ & $0.18^{\mathrm{a}}$ & $1.78^{\mathrm{c}}$ & $4.15^{\mathrm{bc}}$ \\
\hline & CV & 4.35 & 1.78 & 23.95 & 5.82 & 27.2 & 3.97 \\
\hline
\end{tabular}

$\mathrm{CV}=$ Coefficient of Variation.

* Dry basis weight.

Mean values in the same column followed by different superscript letters, from the same region, are significantly different $(\mathrm{P} \leq$ $0.05)$.

Acid factor is a practical parameter which is regularly employed by the cassava starch industry. It is directly related to starch purity, which means that the greater the washing, the lower the acid factor. The results showed higher acid factor in industrial sour cassava starch samples compared to those produced in this work, with no significant alterations in product performance. All the samples showed lower acid factor values than the maximal values established by the CONCEX (1971), $4.50 \mathrm{~mL}$ for type 1 sour cassava starch (Silveira and Cereda, 1987).

Industrial fermentative processes are carried out with a smaller amount of water. Fermentation 
often occurs without the water lamination indicated for cassava starch fermentation. This helped to explain the low acid factor found in this work, where the fermentation was carried out with laminar water for all samples, diluting organic acids in all the sour cassava starch produced in the laboratory.

Different concentrations of glucose syrup did not influence on the final $\mathrm{pH}$ values of the Santa Rosa, Rio do Sul and Tubarão products. Sour cassava starch showed characteristic $\mathrm{pH}$ values for fermented starch. Considering that the fermentation starch $\mathrm{pH}$ values were previously, 4.82; 5.07 and 5.98, a decrease in $\mathrm{pH}$ occurred, which was in accordance with what is found in literature. $\mathrm{pH}$ reduction during the fermentation process corresponds to the release of organic acids and aromatic compounds (Cereda and Lima, 1981;
Aschieri and Vilela, 1995; Plata-Oviedo and Camargo, 1995; Pereira et al., 1999; Demiate et al., 1999).

Starch granule properties can be estimated through viscosity curves, through which the effect of fermentation on starch viscosity can also be observed. Viscoamylographic properties are modified as a result of the fermentative process. Viscosity curves can serve as a guide to starch and its derivative applications (Amante, 1986). Nakamura et al. (1976); Ascheri and Vilela (1995) and Pereira et al. (1999) reported that sour cassava starch viscosity and shaking stability there lower in comparison to cassava starch, and that retrogradation was practically null in sour cassava starch. The results shown in Table 3 confirmed such properties.

Table 3 - Rheological properties of cassava starch (S), industrial sour cassava starch (SS), traditional sour cassava starch $(\mathrm{T})$ and sour cassava starch fermented with $0.10,0.25,0.50 \%$ of glucose, obtained from three different regions of Santa Catarina state (Brazil).

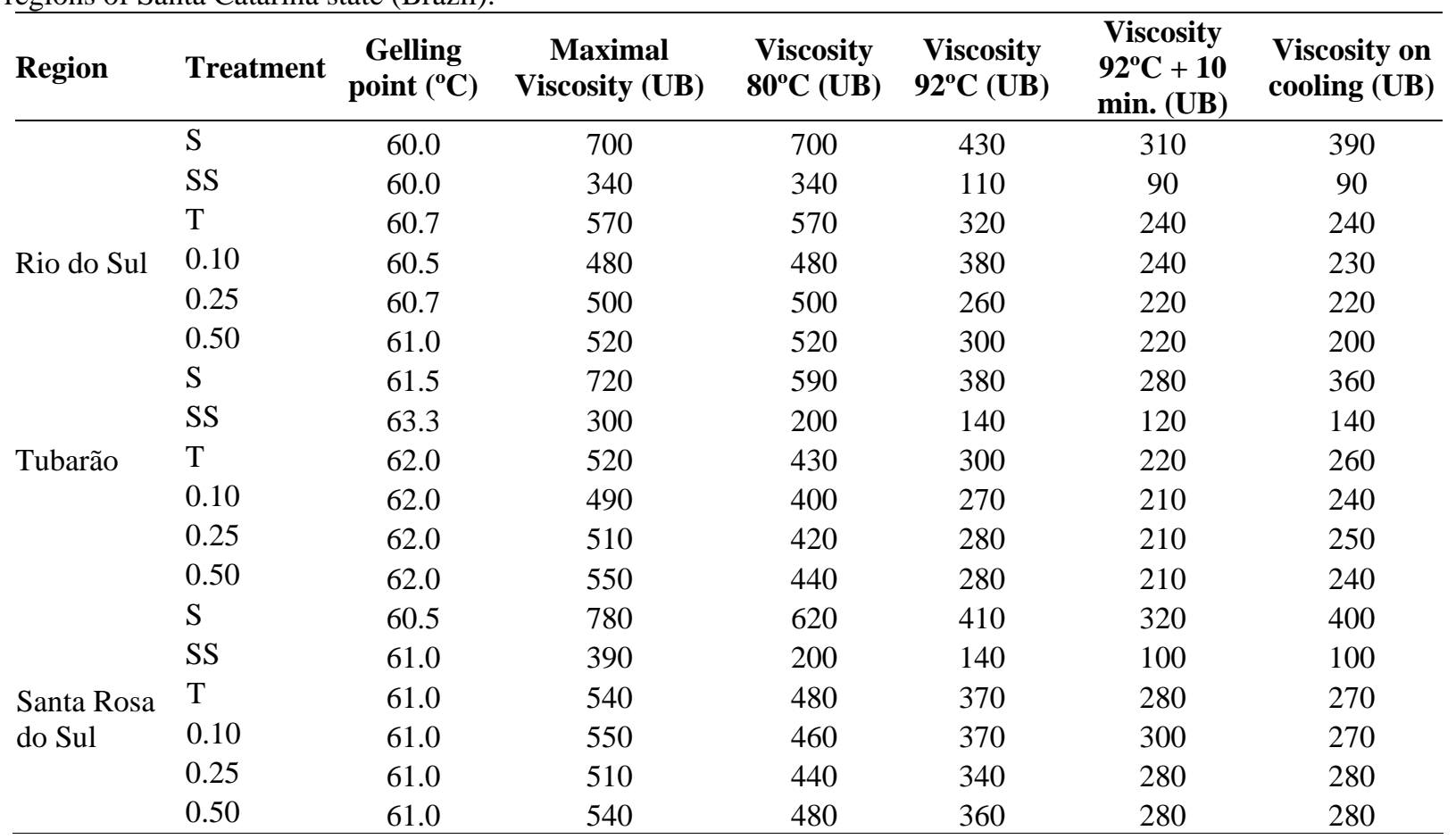

Fermentation effects on starch viscosity are attributed to the action of organic acids produced during fermentative process, which contributes to a decrease in viscosity (Nakamura et al., 1976; Cárdenas and Buckle, 1980; Cereda and Lima, 1981; Ascheri and Vilela, 1995; Plata-Oviedo and Camargo, 1995; Carvalho et al., 1996; Pereira et al., 1999; Maeda and Cereda, 2001). The results of this work showed typical performance values for cassava starch from all the aforementioned locations, with higher maximal viscosity compared to sour cassava starch. In general, the viscosity of the sour cassava starch fermented in this work was higher than that of industrial sour cassava starch. A probable explanation would be its fermentation time since the industrial product showed a higher 
residence time in fermentation, which could contribute to granular weakness and consequent reduction in viscosity.

The gelling point was at around 60 to $62{ }^{\circ} \mathrm{C}$, except for TBSS which was at $63,3{ }^{\circ} \mathrm{C}$. Cassava starch showed higher maximal viscosity and shaking resistance, while all sour cassava starch samples showed lower viscosity on cooling in comparison to cassava starch samples. According to Cereda (1993), the increase in viscosity on cooling was attributed to retrogradation. The retrogradation tendency and the shaking resistance were lower in the sour cassava starch studied in this work than in cassava starch. Through the viscoamylogram, changes in rheological behaviour, which occurred due to fermentation of cassava starch, were verified showing a decrease in maximal viscosity, which was in agreement with previous publications on fermented cassava starch (Ascheri andVilela, 1995).

Cassava starch fermentation results in a product with expansion properties which discard the use of any kind of flour or ferment (Marcon, 2004). According to Ascheri and Vilela (1995) and Maeda and Cereda (2001), expansion in oven cooking constitutes a parameter which can verify the efficiency of the cassava starch fermentative process.

The main concern in proposing Marcon's improved method (2004) was its effect on the expansion property of sour cassava starch. This factor led to the comparison between cassava starch, industrial sour cassava starch, and sour cassava starch produced in the laboratory with different glucose syrup concentrations $(0.10,0.25$ and $0.50 \%$ ). Table 4 showed that the treatment proposed did not influence on the expansion and specific volume of the biscuits produced with sour cassava starch when using the improved method at each of the glucose concentrations employed. No significant differences were found between the expansion capacity of the improved product and the traditional and industrial products; irrespective of their origin $(p>0.05)$. The improved fermentation process of cassava starch did not influence on the main property of the product.

The expansion capacity analysis showed that the cassava starch differed from the sour cassava starch of the same origin. Regarding specific volume, the performance cassava starch was typical, showing significantly different density from the sour cassava starch from the same location. Another notable characteristic of the
Santa Rosa products, in comparison to those from other locations, was their expansion value. They scored the lowest expansion capacity values among the products studied in this work.

The differentiated performance of the Santa Rosa cassava starch, as compared to that of cassava starch from other locations (RSS and TBS), confirmed the variations between origins. This has also been observed by other researchers (Cereda and Lima, 1981; Cereda, 1983; Cereda and Bonassi, 1985; Cereda and Giaj-Levra, 1987; Cereda, 1993; Ascheri and Vilela, 1995). Such variations can be attributed to different intrinsic properties of starch associated with the generation of new compounds during fermentation, with possible influences on product expansion performance.

There are divergences regarding evaluation methodology of sour cassava starch expansion. Some authors refer to density, others to specific volume, and yet others to expansion rate. Such fact results in conflicting data regarding which expansion parameter could be considered ideal (Cárdenas and Buckle, 1980; Ascheri and Vilela, 1995; Plata-Oviedo and Camargo, 1995; Pereira et al., 1999, Maeda and Cereda, 2001).

Considering that the expansion rate evaluation in this work was the same as that carried out by Pereira et al. (1999), the value obtained for expansion capacity of the Santa Rosa products were lower than that of the products from other locations and than those obtained by such authors. Publications and practical information show that decrease of $\mathrm{pH}$ characteristics, increase of product acidity, and reduction in viscosity are parameters that are inversely proportional to the expansion rate and the characteristics of sour cassava starch itself.

All the samples showed that differences in viscosity did not influence on the performance of sour cassava starch in relation to expansion rate (Tables 3 and 4). The expansion rate performance of the Santa Rosa do Sul products did not correspond with their viscoamylographic properties, and although industrial cassava starch showed lower maximal viscosity, this did not influence on their expansion performance. The expansion rate used in sour cassava starch characterisation could well be related to network formation compounds generated during fermentation or sun drying, independent of the viscoamylographic performance of the starch. 
According to Demiate et al. (2000), expansion is attributed to starch granule oxidative degradation caused by ultraviolet radiation during the sun drying process; nonetheless, there is no chemical evidence that proves what kinds of polymers comprise the network responsible for starch expansion.

Aiming at providing the proof of the influence of the improved starch fermentation process, a sensorial acceptability evaluation was performed on samples obtained through the improved method with $0.50 \%$ glucose, which was the quickest process (Marcon, 2004), and compared to industrial sour cassava starch from each of the aforementioned locations. This demonstrated that the improved method did not influence on the sensorial acceptability of the product. The acceptability rate for all samples was higher than $80 \%$ (Table 5). Expansion and sensorial acceptability results showed that the cassava starch improved process did not influence on the characteristics of sour cassava starch. Therefore, its importance in accelerating the fermentative process should be pointed out.

The physiochemical characteristics of sour cassava starch produced through the improved method showed the properties which were very similar to those of either the traditional sour cassava starch produced in industry or the one produced in this work.

Table 4 - Cooked expansion capacity, and density of cassava starch (S), industrial sour cassava starch (SS), traditional sour cassava starch $(\mathrm{T})$ and sour cassava starch fermented with $0.10,0.25,0.50 \%$ of glucose, obtained from three different regions of Santa Catarina state (Brazil).

\begin{tabular}{|c|c|c|c|}
\hline Source & Treatments & Expansion capacity & $\begin{array}{c}\text { Specific volume } \\
{\left[\mathrm{cm}^{3}(\mathrm{~g})^{-1}\right]}\end{array}$ \\
\hline \multirow{7}{*}{ Rio do Sul } & $\mathrm{S}$ & $1.46^{\mathrm{b}}$ & $0.30^{\mathrm{a}}$ \\
\hline & SS & $2.19^{\mathrm{a}}$ & $0.10^{\mathrm{b}}$ \\
\hline & $\mathrm{T}$ & $2.22^{\mathrm{a}}$ & $0.09^{\mathrm{b}}$ \\
\hline & 0.10 & $2.19^{\mathrm{a}}$ & $0.09^{\mathrm{b}}$ \\
\hline & 0.25 & $2.20^{\mathrm{a}}$ & $0.09^{\mathrm{b}}$ \\
\hline & 0.50 & $2.25^{\mathrm{a}}$ & $0.11^{\mathrm{b}}$ \\
\hline & CV & 2.37 & 8.07 \\
\hline \multirow{5}{*}{ Tubarão } & $\mathrm{S}$ & $1.40^{\mathrm{b}}$ & $0.32^{\mathrm{a}}$ \\
\hline & SS & $2.08^{\mathrm{a}}$ & $0.10^{\mathrm{b}}$ \\
\hline & $\mathrm{T}$ & $2.09^{\mathrm{a}}$ & $0.13^{\mathrm{b}}$ \\
\hline & 0.10 & $2.12^{\mathrm{a}}$ & $0.11^{\mathrm{b}}$ \\
\hline & 0.25 & $2.12^{\mathrm{a}}$ & $0.10^{\mathrm{b}}$ \\
\hline \multirow{9}{*}{ Santa Rosa do Sul } & 0.50 & $2.18^{\mathrm{a}}$ & $0.09^{\mathrm{b}}$ \\
\hline & CV & 2.21 & 9.58 \\
\hline & $\mathrm{S}$ & $1.49^{\mathrm{b}}$ & $0.35^{\mathrm{a}}$ \\
\hline & SS & $2.07^{\mathrm{a}}$ & $0.10^{\mathrm{b}}$ \\
\hline & $\mathrm{T}$ & $2.18^{\mathrm{a}}$ & $0.09^{\mathrm{b}}$ \\
\hline & 0.10 & $2.18^{\mathrm{a}}$ & $0.10^{\mathrm{b}}$ \\
\hline & 0.25 & $2.14^{\mathrm{a}}$ & $0.11^{\mathrm{b}}$ \\
\hline & 0.50 & $2.18^{\mathrm{a}}$ & $0.10^{\mathrm{b}}$ \\
\hline & CV & 4.11 & 4.57 \\
\hline
\end{tabular}

Mean values in the same column followed by different superscript letters, from similar region, are significantly different $(\mathrm{P} \leq 0.05)$.

Table 5 - Sensorial acceptability and acceptability rate of industrial sour cassava starch (SS) and sour cassava starch fermented with $0.50 \%$ of glucose obtained through the glucose improved method, from three different regions of Santa Catarina state (Brazil).

\begin{tabular}{lcc}
\hline Sample & Acceptability & Acceptability rate (\%) \\
\hline Rio do Sul SS & $7.84^{\mathrm{a}}$ & 87.11 \\
Rio do Sul 0.5 \% glucose & $7.50^{\mathrm{a}}$ & 83.33 \\
Santa Rosa SS & $7.76^{\mathrm{a}}$ & 86.22 \\
Santa Rosa 0.5 \% glucose & $7.84^{\mathrm{a}}$ & 87.11 \\
Tubarão SS & $7.92^{\mathrm{a}}$ & 88.00 \\
Tubarão 0.5 \% glucose & $7.92^{\mathrm{a}}$ & 88.00 \\
\hline Mean values in the same column followed by different superscript letters are significantly different $(\mathrm{P} \leq 0.05)$.
\end{tabular}


The viscosity of sour cassava starch produced through the improved method was higher than that of industrial sour cassava starch, while showing no influence on the $\mathrm{pH}$, acid factor or its expansion capacity, which was inversely proportional to its viscosity. The improved method sour cassava starch showed differences in viscoamylographic performance according to raw material origin, but did not influence on the expansion performance of the product or its sensorial acceptability. The sour cassava starch expansion occurred without any additional flour or ferment, allowing its utilization in gluten free formulations. Faster processing of cassava starch fermentation could contribute to improving the quality of the final product.

\section{ACKNOWLEDGMENTS}

The authors are grateful to the CIDASC Companhia Integrada de Desenvolvimento Agrícola de Santa Catarina, for allowing the analyses of this research to be carried out in their Physicochemical Laboratory.

\section{RESUMO}

O Polvilho azedo é caracterizado pelas suas propriedades físicas, químicas e reológicas, as quais são diferentes do amido nativo do qual se originou. A propriedade de expansão é uma das mais importantes características do produto, sendo um parâmetro fundamental de avaliação do polvilho azedo. $\mathrm{O}$ resultado do perfil viscoamilográfico também é uma importante maneira de avaliação uma vez que cada amido tem um padrão viscoamilográfico definido de acordo com sua organização granular. Este trabalho determinou o efeito da fermentação melhorada pela adição de glicose, sobre o polvilho azedo, apontando para uma redução no tempo de fermentação e avaliando sua capacidade de expansão, suas propriedades viscoamilográficas e aceitabilidade sensorial. $\mathrm{O}$ processo de produção de polvilho azedo melhorado não prejudicou a expansão do amido, suas propriedades físicoquímicas e sensoriais, mas sim resultou em amidos com diferentes propriedades viscoamilográficas melhores comparativamente ao polvilho azedo produzido pelo processo industrial atual.

\section{REFERENCES}

Amante, E.R. (1986), Caracterização de amidos de variedades de mandioca (Manihot esculenta, Crantz) e de Batata-doce (Ipomoea batatas). Dissertação de mestrado em Ciência e Tecnologia dos Alimentos. Viçosa, Minas Gerais, Brasil.

Ascheri, D.P.R. and Vilela, E.R. (1995), Alterações do polvilho da mandioca pela fermentação, no fabrico de biscoitos. Pesquisa Agropecuária Brasileira, 30, 269279.

Association of Official Analytical Chemists (AOAC) (1999). Official Methods of Analysis of the Association Analytical Chemists, 16th ed. Washington, DC: AOAC.

Balagopalan, C. (2002), Cassava utilization in food, feed and industry. Cassava. In - Biology, Production and Utilization., ed. CAB International., pp. 301-318.

Brasil. (1978), Leis, decretos, etc. Decreto $\mathrm{n}^{\circ}$ 12.486. 20 de outubro de 1978. Normas Técnicas Especiais relativas a Alimentos e Bebidas. D.O. do Estado de São Paulo. 21 de outubro, pp. 3 - 25.

Brasil. (1978), Resolução Concex n ${ }^{\circ} 66$ de 14 de maio de 1971.

Cárdenas, O. S. and Buckle, T.S. (1980), Sour cassava starch production: a preliminary study. J. of Food Sci., 45, 1509 - 1512.

Carvalho, E. P, Canhos, V. P., Ribeiro, V. E. and Carvalho, H. P. (1996), Polvilho Azedo: Aspectos físicos, químicos e microbiológicos. Pesquisa Agropecuária Brasileira, 31, 129 - 137.

Cereda, M. P. and Lima, U. A. (1981), Aspectos sobre a fermentação da fécula de mandioca. II- Controle das fermentações realizadas em laboratório. Boletim da Sociedade Brasileira de Ciência e Tecnologia de Alimentos. Campinas., 15, 107 -122.

Cereda, M. P. (1983), Padronização para ensaios de qualidade da fécula de mandioca fermentada (polvilho azedo). II - Ensaios de absorção de água. Boletim da Sociedade Brasileira de Ciência $e$ Tecnologia de Alimentos. Campinas, 17, 297 - 304.

Cereda, M. P. (1983)a, .Avaliação da qualidade de duas amostras de fécula fermentada de mandioca (polvilho azedo). Boletim da Sociedade Brasileira de Ciência e Tecnologia de Alimentos. Campinas., 17, 305 - 320.

Cereda, M. P. and Bonassi, I. A. (1985), Avaliação da qualidade da fécula fermentada comercial de mandioca (polvilho azedo). III- Ácidos orgânicos e absorção de água. Revista Brasileira de Mandioca, 3, $21-30$. 
Cereda, M. P. (1985)a, Avaliação da qualidade da fécula fermentada comercial de mandioca (polvilho azedo). II-Características físico-químicas e absorção de água. Revista Brasileira de Mandioca., 3, 15-20.

Cereda, M. P. and Giaj-Levra, L. A. (1987), Constatação de bactérias não simbióticas fixadoras de nitrogênio em fermentação natural de fécula de mandioca. Revista Brasileira de Mandioca, 6, 29 33.

Cereda, M. P. (1993), Padronização para ensaios de qualidade da fécula de mandioca fermentada (polvilho azedo). Formulação e preparo de biscoitos. Boletim da Sociedade Brasileira de Ciência $e$ Tecnologia de Alimentos, 17, 287 - 295.

Demiate, I. M., Barana, A. C., Cereda, M. P. and Wosiacki, G. (1999), Organic acid profile of commercial sour cassava starch. Ciência $e$ Tecnologia de Alimentos. Campinas, 19, 131 - 135.

Demiate, I. M., Dupuy, N., Huvenne, J. P., Cereda, M. P. and Wosiacki, G. (2000), Relationship between banking behavior of modified cassava starches and starch chemical structure determined by FTIR spectroscopy. Carbohydrate Polymers, 42, 149 - 158.

Guyot, J. P. and Morlon-Guyot, J. (2001), Effect of different cultivation conditions on Lactobacillus manihotivorans OND $32^{\mathrm{T}}$, an amylolytic lactobacillus isolated from sour starch cassava fermentation. Int. J. of Food Microbiology., 67, 217-225.

Maeda, K.C. and Cereda, M. P. (2001), Avaliação de duas metodologias de expansão ao forno do polvilho azedo. Ciência e Tecnologia de Alimentos, 21, 139143.

Marcon, M. J. A. (2004). Avaliação do processo produtivo para melhoria da qualidade do polvilho azedo. 2004. Dissertação de Mestrado em Ciência dos Alimentos, Universidade Federal de Santa Catarina, Brasil.

Mazurs, E. G., Schoch, T. J. and Kite, F. E. (1957), Graphical analysis of the Brabender viscosity curves of various starches. Cereal Chemistry, 34, 141 - 152.

Meilgaard, M., Civille, G. V. and Carr, B. T. (1999). Sensory Evaluation Techniques. 2th. Boca Raton, FL: CRC Press. 387p.
Mendes Da Silva, C. E., Façanha, S. H. F. and Gomes Da Silva, M. G. (1998), Efeito do teor de água, amilose, amilopectina e grau de gelatinização no crescimento do biscoito de amido de mandioca obtido por fermentação natural. Ciência e Tecnologia de Alimentos, 18, 60-62.

Nakamura, I. M., Moraes, I. O. and Martucci, E. T. (1976), Considerações sobre tecnologia da fécula de mandioca fermentada: produção, propriedades físicoquímicas e aplicações. Científica, 4, 196-202.

Pereira, J. Ciacco, C. F., Vilela, E.R. and Texeira, L.S. (1999), Féculas fermentadas na fabricação de biscoitos: estudo de fontes alternativas. Ciência $e$ Tecnologia de Alimentos, 19, 287-293.

Plata-Oviedo, M. and Camargo, C. R. O. (1995), Determinação de propriedades físico-químicas e funcionais de duas féculas fermentadas de mandioca (polvilho azedo). Ciência e Tecnologia de Alimentos, 15. 59 - 65 .

Riveira, H. H. P. (1997), Fermentação de amido de mandioca (Manihot esculenta, Crantz): avaliação e caracterização do polvilho azedo. Tese de Doutorado em Ciência e Tecnologia de Alimentos, Viçosa, Brasil.

Silveira, I. A., Carvalho, E. P., Schwan, R. I. and Pilon, L. (2000), Aspectos gerais e microbiológicos da fermentação de fécula de mandioca para a produção de polvilho azedo. Higiene Alimentar, 14, 26-31.

Silveira, S. B. and Cereda, M. P. (1987), A fécula da mandioca (polvilho doce). padrões de qualidade para mercado interno e externo. Revista Brasileira de Mandioca, 1, 7-15. 